\title{
Mediating Effect of OCB on Relationship between Job Attitudes and Knowledge Sharing Behavior
}

\author{
Syahri Nehru Husain ${ }^{1}$, Yasir Syam Husain ${ }^{2}$ \\ ${ }^{1}$ Halu Oleo University, Departement of Public Administration, Social Science Faculty, Southeast Sulawesi, Indonesia \\ ${ }^{2}$ Halu Oleo University, Doctoral Programme of Management Science, Southeast Sulawesi, Indonesia
}

\begin{abstract}
This research was conducted to investigate the mediating effect of OCB on relathinship between job attitudes on knowledge sharing behavior. It was based on survey of 100 community facilitators. Structural equation modeling was used to test the hypothesis. The results showed that job attitudes related to insignificantly on knowledge sharing behavior and significantly on OCB. It was caused by the facilitators had a job satisfaction to implicate their ability or skill so that they had a scared on exchange to the role or positions with the other people. They argued that having of ability or skill was an essential asset for their live so they were not sharing its knowledge openly with other and more acted to OCB. It found that OCB correlated a positive significantly on knowledge sharing behavior, but $O C B$ was a weak significant mediator on correlation between job attitudes and knowledge sharing behavior so that in future research may use another variabel to moderate this correlation.
\end{abstract}

Keywords: Knowledge Sharing Behavior, Job Attitudes, Organizational Citizenship Behavior, SEM, Indonesia

\section{Introduction}

Knowledge is a critical organizational resource that provides a sustainable competitive advantage in a dynamic and competitive economy (Davenport., et al., 1998). Knowledge is considered as a value that makes competitive advantage to survive and remain in the market. The knowledge possessed by the firm is a strategic resource that can create a competitive advantage (Demsetz, 1988, Spender, 1996). Knowledge sharing is one of knowledge management which is as a process of knowledge exchange in the form of skills, experiences, and capabilities among co-workers or employees. Knowledge sharing refers to the preparation of information and knowledge to task of working with other people who can help a person to solve their problems, policies, or development of new ideas. (Pulakos et al., 2003). Knowledge sharing effectively contributed to increase productivity and profitability, including earnings and sales growth (Magnus dan DeChurch, 2009) to share ideas, knowledge and experiences in decision-making, problemssolving and innovation of new ideas. Moreover, knowledge was held by employees must be spread and shared with others as a strategy to maintain knowledge (Cabrera et al., 2006) and to minimize employee intent to leave the business (Hansen, 1999). However, knowledge sharing has a few barriers. They are the lack of time, loss of awareness in knowledge management, and lost consciousness to knowledge (Leistner, 2010). The barriers occured because knowledge was created and stored in the organization's members (Chow dan Chan, 2008), individual employees were less likely to share their knowledge (Ho et al., 2009). The sticky in transferring knowledge was a key issue in the firm, because the transfer of knowledge within the firm takes time, incurs costs, and uncertainty (Szulanski, 2003). Knowledge sharing behavior was generally not reasonable because people considered their knowledge as a valuable asset, and sharing of knowledge widely with others limited by the natural tendency to keep their information (Davenport and Prusak, 1998, cited Hsu et al., 2007). The reluctance of employees to share their knowledge with colleagues created problems for survival of the organization (Lin, 2007).

The results showed that the primary determinant of knowledge sharing behavior are job attitudes (Teh and Sun, 2012) and OCB (Teh and Yong, 2011; Teh and Sun, 2012). Teh and Sun (2012) found that job involvement and job satisfaction significantly influence on OCB and knowledge sharing behavior. Its reasons that firm employees have a highly job involvement and job satisfaction. Job Attitudes have had impact both on knowledge sharing behavior and organizational citizenship behavior (Jofreh et. al., 2014). Similarly, organizational citizenship behavior have had impact also on knowledge sharing behavior (Jofreh et. al., 2014, Husain, Y.S., 2015). However, organizational citizenship behavior could not mediate the correlation between job attitudes and knowledge sharing behavior (Teh dan Sun, 2012). Organizational citizenship behavior

\section{Review of Literature}

\section{Knowledge Sharing Behavior}

Knowledge sharing is that activity where agents (individuals, communities or organizations) exchange their knowledge (informations, skills or expertises). It is linked to the knowledge management process, which can be broadly characterized by four activities, the creation, storage and retrieval, transfer and application of knowledge (Ireson \& Burel, Knowledge Sharing in eCollaboration, 2010). Davenport and Prusak (1998) defined knowledge as "Knowledge is a fluid mix of framed experiences, values, contextual information, and expert insight that provide a framework for evaluating and incorporating new experiences and information". Knowledge sharing behavior is spread and share knowledge that has a value possesed other members in the organization (Ryu et al., 2003). Knowledge sharing was supported with different purposes, they are : to acquire knowledge, to reuse knowledge, and to develop new knowledge (Huysman and DeWit, 2002). 


\section{International Journal of Science and Research (IJSR) \\ ISSN (Online): 2319-7064 \\ Index Copernicus Value (2013): 6.14 | Impact Factor (2014): 5.611}

Knowledge sharing gains its importance from the role it plays over enhancing the overall performance of any organization, and the competitive advantages it adds to the corporate. Knowledge sharing is widely recognized to be a main component of successful knowledge management, and one of the central characteristics of healthy knowledge culture is that knowledge sharing is embedded in the way in which organization works (Seba, et. al., 2012). According to Lin (2007), knowledge sharing is fundamental to generate new ideas and developing new opportunities through the socialization and learning process of employees. Knowledge sharing plays an essential role in the organizational process because it helps an organization to transfer new ideas or solutions (Islam et al., 2010). Knowledge sharing is believed to be influenced by factors both at individual and organizational level (Naftanaila, 2010). At the individual level, one of the most important factors affecting knowledge transfer process is trust. According to (Lilleoere \& Hansen, 2011), Some of the knowledge sharing barriers that exists are : no knowledge of where knowledge is available, no knowledge about the existence of valuable knowledge, not having access to the knowledge, the assumption that knowledge equals power, and large physical and social distance between individuals. Szulanski (1996) found that knowledge sharing is inhibited by three major factors:

1) Lack of absorptive capacity of the recipient.

2) Casual ambiguity concerning the knowledge itself.

3) An arduous correlation between the sender and the receiver.

\section{Job Attitudes}

Theory of reasoned action (Ajzen and Fishbein, 1975) and theory of planned behavior (Ajzen, 1991) stated that a person's behavior was determined by the intention to behave and intention to behave was determined by attitudes to behavior, subjective norms and control of perceived behavioral. Both theories are then applied to predict the influence factors on knowledge sharing behavior. Bock (2002) stated that the knowledge sharing behavior is determined by the intention to behave and intention to behave is determined by the attitudes to share knowledge. Ryu et al. (2003) argued that TPB as a theory which is considered a success in predicting knowledge sharing behavior.

Job attitude consists of three main components, namely job involvement, job satisfaction, and organizational commitment (Schermerhorn et al, 2012; Robbins and Judge, 2013). Job attitudes and OCB were latent construct of knowledge sharing behavior (Teh and Sun, 2012, Jofreh et al., 2014). The study showed that the attitude to share knowledge has a positive affects to intention for behave and then also affects on knowledge sharing behavior (Bock, 2002; Ryu et al., 2003; Lin et al., 2004; Chatzoglou and Vraimaki 2009; Tohidinia and Mosakhani, 2010; Jeon et al., 2011; Casimir et al., 2012; Zang and $\mathrm{Ng}$, 2012; Teh and Sun, 2012, Jofreh et al., 2014). Results of the study explained that the more of job attitudes to share knowledge, the higher intention to share knowledge so that it improves the level of knowledge sharing behavior of employees. However, the study results indicated that job attitude has a significant negative effect on the intention to knowledge sharing (Teh and Yong, 2011). Furthermore, the higher of employee attitudes to knowledge sharing results, the lower intention of employees to knowledge sharing.

Therefore, it can be concluded that the more of job attitudes, the higher of knowledge sharing behavior. Otherwise, the lower of job attitudes, knowledge sharing behavior will be decreased. The existence of such differences, it's proposed the hypotheses as follows:

H1: Job Attitudes has a significant positive effect on knowledge sharing behavior.

The study showed that job satisfaction has a significantly influence to OCB (Huang et al., 2012; Teh and Sun, 2012; Jofreh et al, 2014). Job involvement also showed that it has a significant effect on OCB in organizations (Ueda, 2012; Teh and Sun, 2012; Jofreh et al, 2014). Moreover, organizational commitment has a significant influence on OCB organizations (Williams and Anderson, 1991; Schappe, 1998; Ueda, 2012; Jofreh et al, 2014). Thus, the more of job involvement, job satisfaction, and organizational commitment: the higher of OCB employees in the organizations. However, another study found that job satisfaction (Schappe, 1998; Mohamed et al., 2012; Huang et al., 2012) and organizational commitment (Williams and Anderson, 1991; Huang et al., 2012; Teh and Sun, 2012) has no significant effect on OCB individual. Furthermore, the improving of job satisfaction and organizational commitment would not be given a growth to OCB individual.

Furthermore, it can be concluded that the more of job attitude, the higher of OCB. On the contrary, the lower of job attitudes, OCB will be decreased. The existence of such differences, it's proposed the hypotheses as follows:

$\mathrm{H} 2$ : Job attitude has a significant effect on organizational citizenship behavior (OCB).

\section{Organizational Citizenship Behavior}

Social exchange theory (Blau, 1964), stated that knowledge sharing is one of the social interaction. One underlying this theory showed that knowledge sharing occurs because of reprisal act received like job security, status, balance of power and the maintenance of future relations (Bock et al., 2005; Cabrera and Cabrera, 2005; Jarvenpaa and Staples, 2001; Muthusamy et al., 2007), and then investigate motivation of OCB employee. OCB is a discretion behavior and undirectly or explicitly appreciated in the context of official awards in organizational structure, but it contributed positively to organizational performance (Jarvenpaa and Staples, 2001; O'Donohue et al., 2007; Zboralski, 2009). Knowledge sharing is a form of OCB behavior that will be voluntary actions which help contribute to organizational competitive advantage. Organ (1988) stated that OCB is a discretionary individual behavior. Such behavior is undirectly or explicitly recognized by the formal reward system and the overall effectiveness of the functions that support organization. Organ (1988) suggested that there were five specific categories of behavior discretion that can help increase the efficiency of the organization. They are altruism, conscientiousness, sportsmanship, courtesy, and civic virtue. 


\section{International Journal of Science and Research (IJSR) \\ ISSN (Online): 2319-7064}

Index Copernicus Value (2013): 6.14 | Impact Factor (2014): 5.611

OCB is a partial mediator (Islam et al 2012; Troena \& Noermijati, 2013; Sani, 2013). The study showed that OCB has a significant effect on knowledge sharing behavior (AlZu'bi, 2011; Ramasamy and Thamaraiselvan 2011; Teh and Yong, 2011; Islam et al., 2012; Teh and Sun, 2012). It means that the more of OCB employee, the higher of employee knowledge sharing behavior. However, OCB is not be able to mediate correlation between job attitudes and knowledge sharing behavior (Teh and Sun, 2012), and has no significant effect on tacit of knowledge sharing behavior (Wimbarti, 2014). Therefore, an increasing of OCB would not be given a significant effect to improve correlation between job attitudes and tacit of knowledge sharing behavior.

Moreover, it can be concluded that the improving of OCB would be affect the growth of knowledge sharing behavior.
On the contrary, the lower of OCB would be produce knowledge sharing behavior in lower. Furthermore, the improving of OCB will be able to mediate job attitudes and knowledge sharing behavior. Otherwise, the lower of OCB would not be able to mediate the job attitudes on knowledge sharing behavior. The existence of such differences, it's proposed the hypotheses as follows:

H3: Organizational citizenship behavior has a significant effect on knowledge sharing behavior

H4: Organizational citizenship behavior has a significant effect in mediating of job attitudes on knowledge sharing behavior.

Thus, conceptual framework in this study can be seen in the following Figure.

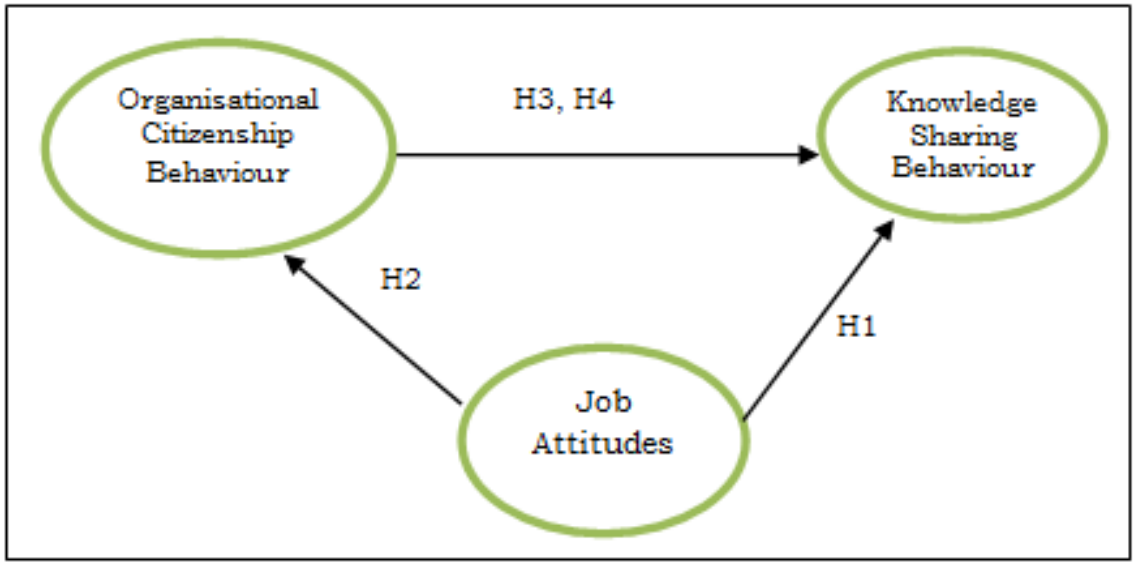

Source: Developed by the author based on the data available.

Figure 1: Conceptual Framework

\section{Research Methodology}

\section{Samples}

The samples for the present study consisted of 100 facilitators from selected 62 facilitators of P2KP, and 38 facilitators of SINTESA in Indonesia. The data were collected during the period of August 2015-November 2015 using a questionnaire and by personally visiting the organizations. The sample had 67 men (67.00 per cent) and 33 women (33.00 per cent). The sample had their age varying between 20 years and 60 years which consists of a respondent aged 20 years old, 27 respondents among 21-30 years old, 52 respondents among 31-40 years old, and 20 respondents was over 40 years old. Also, the sample had 90 graduates ( 90.00 per cent), 6 undergraduates ( 6.00 per cent), and 4 senior hight school (4.00 per cent) as far as their education levels were concerned. Of the samples, 57.00 per cent were field facilitators', 20.00 per cent were administrative personnels', 11.00 per cent were middle managements', 10.00 per cent were supervisors, and 2.00 per cent were managers. The work experience of the samples was also mixed: below 5 years (61.00 per cent), in between 6 and 10 years (31.00 per cent) and more than 10 years $(8.00$ per cent).

\section{Measures}

Standardised instruments were used for collecting the data. There were three indicators for measuring job attitude (JA) developed by Robbins dan Judge (2013); and Teh and Sun
(2012). Job involvement was the first indicator in this scale and measured using four items developed by Kanungo (1982). Job satisfaction was the second indicator in this scale and measured using six items developed by Weiss et al. (1967). Organizational commitment was the third indicator in this scale and measured using five items developed by Allen and Meyer (1990). Organizational citizenship behavior (OCB) is measured based on five main indicators developed Organ (1988). Altruism was the first indicator in this scale and measured using three items. Civic virtue was the second indicator in this scale and measured using four items. Concentiousness was the third indicator in this scale and measured using four items. Courtesy was the fourth indicator in this scale and measured using three items. Sportmanship was the fifth indicator in this scale and measured using three items. Knowledge sharing behavior (KSB) is measured based on two main indicators developed by De Vries et al.(2006); and Tohidinia dan Mosakhani (2010). Knowledge donation was the firsth indicator in this scale and measured using four items. Knowledge collection was the second indicator in this scale and measured using four items. The employee responded on a 5-point Likert scale ( 1 means strongly disagree, 5 means strongly agree).

\section{Data Analysis and Result}

Statistic descriptive was used to describe the variable in generally. The mean and standar deviation of job involvement was $(\mathrm{M}=3.89, \mathrm{SD}=0.65)$, job satisfaction was $(\mathrm{M}=3.84, \mathrm{SD}=0.54)$, and organizational commitment was 


\section{International Journal of Science and Research (IJSR) \\ ISSN (Online): 2319-7064}

Index Copernicus Value (2013): 6.14 | Impact Factor (2014): 5.611

$(\mathrm{M}=3.60, \mathrm{SD}=0.66)$. Moreover, the descriptive score of altruisme was $(\mathrm{M}=3.88, \mathrm{SD}=0.61)$, civic virtue was $(\mathrm{M}=3.70, \quad \mathrm{SD}=0.49), \quad$ concentiousness was $\quad(\mathrm{M}=3.84$, $\mathrm{SD}=0.58)$, courtesy was $(\mathrm{M}=4.01, \quad \mathrm{SD}=0.58)$, and sportsmanship was $(\mathrm{M}=3.94, \quad \mathrm{SD}=0.65)$. Thus, The descriptive score of knowledge donation was $(\mathrm{M}=3.89$, $\mathrm{SD}=0.58)$ and knowledge collection was $(\mathrm{M}=3.85$, $\mathrm{SD}=0.50)$.

Confirmatory factor analysis was processed using AMOS 22 to test the strengthen of indicator variable to confirm the research variable which lamda value should be in range $\geq$ 0.40 (Ferdinand, 2005). Job attitude had been confirmed by three indicators. They were job involvement which had $\lambda$ of 0.63 , job satisfaction which had $\lambda$ of 0.82 , and organizational commitment which had $\lambda$ of 0.69 . Moreover, organizational citizenship behavior had been also confirmed by five indicators. They were altruism which had $\lambda$ of 0.53 , civic virtue which had $\lambda$ of 0.53 , and concentiousness which had $\lambda$ of 0.58 , courtesy which had $\lambda$ of 0.66 , and ortsmanship hich had $\lambda$ of 0.62 . Furthermore, knowledge sharing behavior had been confirmed by two indicators. They were knowledge donation which had $\lambda$ of 0.83 , and collecting knowledge which had $\lambda$ of 0.69 .

Finally, to test the hypotesses was performed throught structural equation model (SEM) processed by AMOS 22. The test results Structural Equation Model can be seen in following Figure.

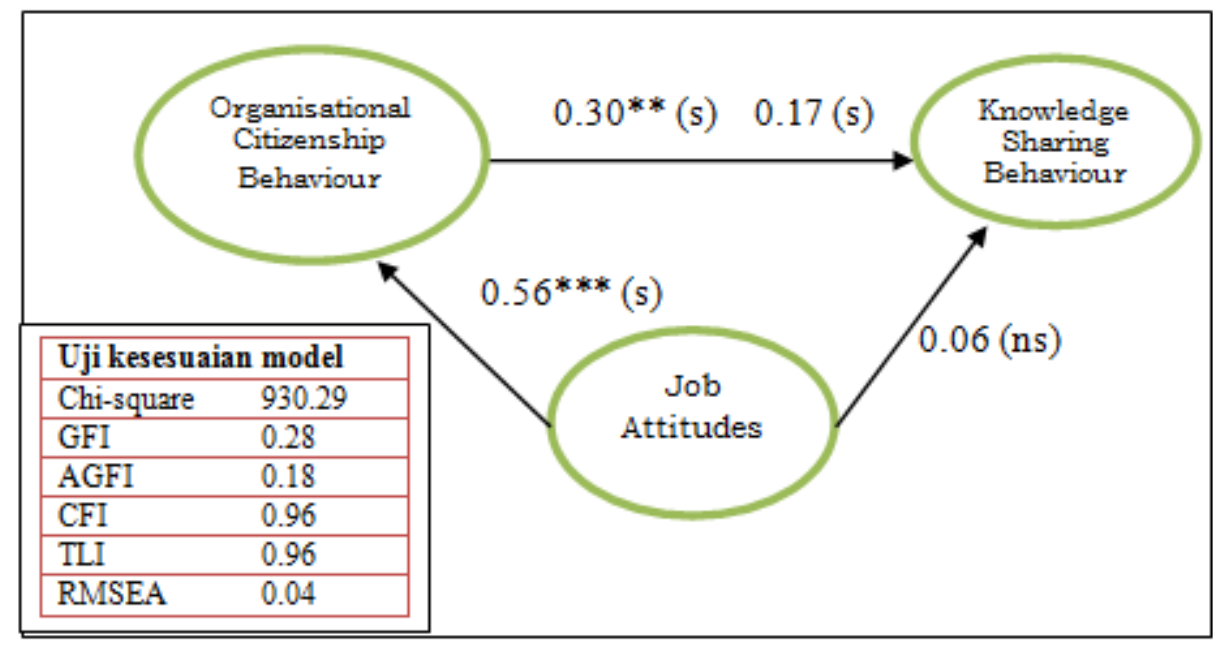

Figure 2: Structural Equation Model

The results as shown on Figure 2, that the direct affect of job attitudes on knowledge sharing behavior was 0.06 (ns), and toward organizational citizenship behavior was 0.56 (s). Next, the affect of organizational citizenship behavior on knowledge sharing behavior was 0.30 (s), and mediating of organizational citizenship behavior to job attitudes toward knowledge sharing behavior was 0.17 (s). The contribution value that had been explained could be seen in following Table.

Table 1: Contribution Value

\begin{tabular}{|c|c|c|c|}
\hline Effect & Variable & OCB & KSB \\
\hline \multirow{2}{*}{ Directly } & JA & $0.56^{* * *}(\mathrm{~s})$ & $0.06(\mathrm{~ns})$ \\
\cline { 2 - 4 } & OCB & & $0.30^{* *}(\mathrm{~s})$ \\
\hline Mediation & OCB & & $0.17(\mathrm{~s})$ \\
\hline
\end{tabular}

Note: $* * *$ Significant at $\alpha<0.01$

$* *$ Significant at $\alpha<0.05$

The model is to be feasible if at least one method of testing the feasibility of the model is fulfilled because in practice it is very difficult to meet the five test feasibility. However, when testing the feasibility of the model can meet more than one eligibility criterion model, SEM will be much better than only one who fulfilled (Widarjono, 2010). The model as shown in Figure 2, showed that the value of CFI was 0.96 , TLI was 0.96 , and RMSEA was 0.04 . It was stated by Hair et al. (1995) that the value of CFI and TLI $\geq 0.95$ and RMSEA $\leq 0.08$ were within the expected range of values that could be accepted. Therefore, it could be accepted eventhought the value of Chi-square, GFI and AGFI were not within the expected value. Finally, it could be concluded the hypotesses that previous proposed as following:

$\mathrm{H} 1: \mathrm{JA} \rightarrow \mathrm{KSB}=$ rejected

$\mathrm{H} 2: \mathrm{JA} \rightarrow \mathrm{OCB}=$ accepted

$\mathrm{H} 3: \mathrm{OCB} \rightarrow \mathrm{KSB}=$ accepted

$\mathrm{H} 4: \mathrm{JA} \rightarrow \mathrm{OCB} \rightarrow \mathrm{KSB}=$ accepted

\section{Discussion}

The results showed that the job attitude has a positive unsignificant effect to knowledge sharing behavior. Hypothesis (H1) stated that the job attitudes has a significant effect on knowledge sharing behavior can not be accepted or rejected in which the results showed that the job attitudes has not a significant effect on the knowledge sharing behavior. The contribution value was arounds 0.06 at the level of $\alpha>0.05$. Therefore, a good job attitude by the facilitators in implementing community assistance could not give effect to increase knowledge sharing behavior better. Results found that job attitudes has unsignificant effect on knowledge sharing behavior, contrast with Teh and Sun (2012) research who stated that the job attitudes has significant effect to knowledge sharing behavior. It means that the higher of employees' job satisfaction, the lower of knowledge sharing behavior. A good job satisfaction was not guaranted to be able to share their knowledge with colleagues because of knowledge is existed in individual itself so it's difficult to share. According to Ajzen dan 


\section{International Journal of Science and Research (IJSR) \\ ISSN (Online): 2319-7064 \\ Index Copernicus Value (2013): 6.14 | Impact Factor (2014): 5.611}

Fishbein (1975) in their theory "theory of reasoned action (TRA)" stated that the individual intention is the main reason to behave which determined by attitude and subjective norms. Besides, Ajzen (1991) in his theory "theory of planned behavior (TPB)" then add the factor of intention was also determined by perceived behavioral of control. This finding has been confirmed by research likes Bock and Kim (2002); Lin et al. (2004); Chatzoglou and Vraimaki (2009); Chen et al. (2009); Tohidinia and Mosakhani (2010); Jeon et al. (2011); Zang and Ng (2012); and Yang (2008).

The results showed that job attitude has significant positive effect on OCB. Hypothesis (H2) stated that the job attitude has significant effect on OCB acceptable or can not be rejected where the results showed that job attitude has significant positive effect on OCB. The contribution value was arounds 0.56 at the level of $\alpha \leq 0.01$ that could be accepted. Therefore, good facilitators' job attitude will increase OCB facilitators in assisting the community. Having knowledge that provide job remains is the main reason for the facilitators to satisfy on a regular job so that they are more favorable to behavior of discretion and act outside of responsibility or called OCB. This finding is supported by several studies likes Schappe (1998); Huang et al. (2012); and Jofreh et al. (2014).

The study found that the OCB has a significant positive effect on knowledge sharing behavior. Hypothesis (H3) stated that OCB has a significant effect acceptable or may not be refused where the results showed that OCB has a significant positive effect on knowledge sharing behavior. The contribution value was arounds 0.30 at the level of $\alpha \leq$ 0:05 that could be accepted accepted. Therefore, good facilitators' OCB will improve knowledge sharing behavior facilitators in assisting the community. Delivering of the basic things associated with the job is the biggest factor that makes them have courtesy to share knowledge to their colleagues. This finding is consistent with Teh and Sun (2012) research who stated that job attitudes has a significant effect on knowledge sharing behavior. This finding is also supported by various studies such as Al-Zu'bi (2011); Ramasamy and Thamaraiselvan (2011); Teh and Yong (2011); Islam et al. (2012); Hsu and Lin (2008); and Susanti and Wimbarti (2012).

The study showed that OCB has a positive effect in mediating job attitudes on knowledge sharing behaviors. Hypothesis (H4) who stated that organizational citizenship behavior have a significant effect in mediating the correlation between job attitudes and knowledge sharing behavior was acceptable or could not be rejected. In mediating of contribution was arounds 0.17 that could be accepted. The results showed that the organizational citizenship behavior has mediated job attitudes on knowledge sharing behavior positive significantly. Moreover, OCB has an important role in mediating of job attitude toward knowledge sharing behavior, but it weaks so that could be said that OCB was a weak significant mediator of job attitudes. A good courtesy was a fundamental matters related to employment which as the biggest factor that makes them have courtesy to share knowledge to their colleagues. This finding is inconsistent with Teh and Sun (2012) research stated that OCB can not mediate the correlation between job attitudes and knowledge sharing behavior. Furthermore, it is one of reason for employee to more share their knowledge with colleagues who can be trusted. In connection with this finding that stated the OCB as a discretionary behavior is still pay attention for the element of trust with co-workers because of knowledge sharing will occur a reprisal act received such as job security, status, balance of power and the maintenance of a future relations. This is supported by Bock et al. (2005); Cabrera and Cabrera (2005); Jarvenpaa and Staples (2001); Muthusamy et al. (2007.

\section{Conclussion}

Based on the results of this study, it can be concluded that: firstly, job attitudes has a positive unsignificant effect on knowledge sharing behavior. Secondly, job attitude has a positive significant effect on organizational citizenship behavior. Thirdly, organizational citizenship behavior has a positive significant effect on knowledge sharing behavior. Finally, organizational citizenship behavior has a positive effect in mediating of job attitudes on knowledge sharing behavior.

\section{Limitations}

This study only has three indicators of job attitudes and five indicators of OCB where there were other indicators which could form the variable of job attitudes and OCB. The determination factor of knowledge sharing behavior has still remained another factor that unreaches in this research. The study showed that job attitude has no significant effect on knowledge sharing behavior caused by the contribution of other factors. Thus, it was needed another variables that could moderate this correlation. The samples of this research were facilitators of non-profit organizations so that it has a possibility to differ of knowledge sharing behavior with othe profession. The data of this research was using a crosssectional data, therefore is not sufficient accurately to generalize out of time from this survey. Finally, an individual's perception regarding anything can change at any time.

\section{Future Research}

Another indicators of job attitudes and another indicators of OCB may be used to investigate the correlation toward knowledge sharing behavior in future research. Another variable could be examined as influence factor of knowledge sharing behavior in future research. The correlation between job attitudes and knowledge sharing behavior that has unsignificant effect so that for future research may investigate using a mediator variabel. OCB has a mediator role the correlation between job attitudes and knowledge sharing behavior, but this correlation stiil weak so that in future research may use another variabel to moderate this correlation. The samples of this research were facilitators of non-profit organizations so that in future research may come from another profession. Future research may design a longitudinal study to test the model of knowledge sharing behavior. 


\section{International Journal of Science and Research (IJSR) \\ ISSN (Online): 2319-7064}

Index Copernicus Value (2013): 6.14 | Impact Factor (2014): 5.611

\section{References}

[1] Ajzen, I. (1991). The Theory Of Planned Behavior. Organizational Behavior and Human Decision Processes, 50, 179-211.

[2] Ajzen, I., \& Fishbein, M.(1975). Belief, Attitude, and Intention behavior: an introduction to theory and research. Addison-Wesley Publishing Company.

[3] Albaraccin (2005). The Handbook of Attitudes. Lawrence Erlbaum Associates, Publishers Mahwah, New Jersey London.

[4] Al-Zu'bi, H.A.(2011). Organizational Citizenship Behavior And Impacts On Knowledge Sharing: An Empirical Study. International Business Research. Vol. 4, No. 3.

[5] Bidokhti A, Hosseini S.H., Ehsani Z. (2011). Relationship Between Organizational Culture And Knowledge Management In Educationc Organization Of Semnan. No. 59:191-216

[6] Blau, P.M.(1964). Exchange and Power in Social Life. Wiley, New York, NY.

[7] Bock, G. W. Zmud, R. W., Kim, Y. G., and Lee, J. N.(2005). Behavioral Intention Formation In Knowledge Sharing: Roles Of Extrinsic Motivators, Social-Psychological Forces, And Businessal Climate. MIS Quarterly, Vol.29, No.1, pp. 87-112 .

[8] Bock, G.W., \& Kim, Y.G.(2002). Breaking The Myths Of Rewards: An Exploratory Study of Attitudes About Knowledge Sharing. Information Resources Management Journal, Vol. 15 No. 2, pp. 14-21.

[9] Cabrera, A., \& Cabrera, E.F.(2002). KnowledgeSharing Dilemmas, Organizational Studies, Vol. 23, pp. 687-710.

[10]Cabrera, A., Collins, W., Salgado, J. (2006). Determinants of Individual Engagement In Knowledge Sharing. International Journal of Human Resource Management; 245: 17-2

[11] Casimir, G., Lee, K., \& Loon, M. (2012). Knowledge Sharing: Influences of Trust, Commitment And Cost. Journal Of Knowledge Management. Vol. 16 No. 5, Pp. 740-753, Emerald Group Publishing Limited, Issn 1367-3270. Doi 10.1108/13673271211262781

[12] Chatzoglou, P.D., \& Vraimaki, E.(2009). KnowledgeSharing Behavior of Bank Employees In Greece. Business Process Management Journal, Vol. 15 No. 2. pp. 245-266, Emerald Group Publishing Limited 14637154. DOI 10.1108/14637150910949470

[13] Chow, W.S., \& Chan, L.S.(2008). Social Network, Social Trust And Shared Goals In Organizational Knowledge Sharing. Information \& Management, Vol. 45 No. 7, pp. 458-65.

[14] Cyert, R. M., \& March, J. G.(1963). A behavioral theory of the firm . Englewood Cliffs, NJ: PrenticeHall.

[15]Davenport, T.H., \& Prusak, L.(1998). Working Knowledge: How Organizations Manage What They Know. Harvard Business School Press, Boston, MA.

[16] Demsetz, Harold (1988). The Theory Of The Firm Revisited , Journal of Law, Economics, and Organization, 141-161.

[17]Ellinger A.D., Ellinger A.E., Yang. B., Howton SW.(2002). The Relationship Between The Learning Organization Concept And Firms' Financial
Performance: An Empirical Assessment. Human Resource Development

[18]Ferdinand, 2005. Structural Equation Modelling Dalam Penelitian Manajemen. Semarang, BP UNDIP.

[19] Goudarzi, M., Abutorabi, M., Dastigardi, M., \& Dastigardi, K. (2009). Relationship Between Organizational Culture And Knwledge Management In Directors of Physical Education Organization; J. Sport Manage. (motion). 6(2):201-214.

[20] Guo, Y., Wang,C., \& Feng, Y. (2014). The Moderating Effect of Organizational Learning Culture on Individual Motivation and ERP System Assimilation at Individual Level. Journal of Software, Vol 9, No 2 (2014), 365373, doi:10.4304/jsw.9.2.365-373

[21] Hair, J. F. Jr., Anderson, R. E, Tatham, R. L. \& Black, W. C. (1995). Multivariate data analysis. New Jersey, Prentice Hall International Editions.

[22] Hansen, M.T., Nohria, N., \& Tierney, T. (1999). What's Your Strategy For Managing Knowledge?. Harvard Business Review, pp. 106-16.

[23] Ho, C.T.B., Hsu, S.F., \& Oh, K.B.(2009). Knowledge Sharing: Game And Reasoned Action Perspectives, Industrial Management \& Data Systems, Vol. 109 No. 9, pp. 1211-30.

[24] Holotezi, A.,(2002). The Relationship Between Knowledge Management And Organizational Culture. Applied Information Management And The Gradute School Of The : J. university of orergon, 3(2):15-22

[25]Hsu, M.H., Ju, T.L., Yen, C.H., \& Chang, C.M.(2007). Knowledge Sharing Behavior In Virtual Communities: The Relationship Between Trust, Self-Efficacy, And Outcome Expectations. International Journal of Human-Computer Studies, Vol. 65, pp. 153-69.

[26]Huang, C.C., You, C.S., \& Tsai, M.T.(2012). A Multidimensional Analysis of Ethical Climate, Job Satisfaction, Organizational Commitment, And Organizational Citizenship Behaviors. sagepub.co.uk/journals Permissions.nav 10.1177/0969733011433923 nej.sagepub.com

[27]Huber, G. P.(1991). Organizational Learning: The Contributing Processes and The Literatures. Organization Science, 2 , 88-115.

[28] Husain, Y.S., Sarita, B., Syarifuddin, D.T., Nurwati, 2015. The Role of Organizational Learning Culture to Organizational Citizenship Behavior toward Knowledge Sharing Behavior. International Journal of Science and Research (IJSR) ISSN (Online): 2319-7064

[29] Huysman and Dewit (2002). Knowledge Sharing In Practice. Springer Science+Business Media, B.V.

[30] Idris, K.M., Nita, A.K., \& Godwin, A.U.(2015). Impact Of Organizational Culture On Knowledge Management Process In Construction. Asian Social Science; Vol. 11, No. 9. ISSN 1911-2017 E-Issn 1911-2025

[31] Ireson , N., \& Burel, G.(2010). Knowledge Sharing in eCollaboration.

[32] Islam Z, Ahmad ZA, Mahtab H (2010). The Mediating Effects of Socialization On Organizational Contexts And Knowledge Sharing. J. Knowl. Global. 3(1): 31-48.

[33] Islam, M.Z., Ahmed,S.M., Hasan, I., \& Ahmed, S.U. (2011). Organizational Culture And Knowledge Sharing: Empirical Evidence From Service Organizations. African Journal of Business Management Vol. 5(14), pp. 5900-5909. Available 


\section{International Journal of Science and Research (IJSR) \\ ISSN (Online): 2319-7064}

Index Copernicus Value (2013): 6.14 | Impact Factor (2014): 5.611

online at http://www.academicjournals.org/AJBM DOI: 10.5897/AJBM11.073 ISSN 1993-8233

[34] Islam, T., Anwar,F., Rehman Khan, S.U, Rasli, A., Norulkamar, U., Ahmed, I. (2012). Investigating The Mediating Role of Organizational Citizenship Behavior Between Organizational Learning Culture And Knowledge Sharing. World Applied Sciences Journal 19 (6): 795-799, 2012 ISSN 1818-4952, DOI: 10.5829/idosi.wasj.

[35] Issa, Raja R.A., \& Haddad, Josef. (2008). Perceptions of The Impacts of Organizational Culture and Information Technology on Knowledge Sharing In Construction. Construction Innovation. Vol. 8 No. 3, 2008 pp. 182201. Emerald Group Publishing Limited.14714175.DOI 10.1108/14714170810888958

[36] Jansen, J. P. J., Van Den Bosch, F. A. J., \& Volberda, H. W. (2006). Exploratory Innovation, Exploitative Innovation and Performance: Effects of Organizational Antecedents And Environmental Moderators. Management Science, 52 (11), 1661-1674.

[37] Jarvenpaa, S.L., \& Staples, D.S. (2001). Exploring Perceptions of Organizational Ownership of Information And Expertise. Journal of Management Information Systems, Vol. 18 No. 1, pp. 151-83.

[38] Jeon, S., Gul Kim, Y., \& Koh, J. (2011). An Integrative Model For Knowledge Sharing In Communities-OfPractice. Journal of Knowledge Management. Emerald Group Publishing Limited, ISSN 1367-3270 J. Vol. 15 No. 2, pp. 251-269.. Doi 10.1108/13673271111119682

[39] Jofreh, M., Aghaei,T., \& Mamqani, N.B. (2014). Investigating The Impact of Job Attitudes on Organizational Citizenship Behavior And Knowledge Sharing. Journal of Educational and Management Studies. J. Educ. Manage. Stud.,4 (2): 332-337, 2014. ISSN: 2322-4770

[40]Karimi,F., \& Akbari, M. (2013). Predicting Organizational Citizenship Behavior on the Basis of Organizational Learning Capability. Middle-East Journal of Scientific Research 18 (9): 1371-1379, DOI: 10.5829/idosi.mejsr. 2013.18.9.12381

[41] Kouchaki M., Ghayoomi A., \& Moradi N., (2012). Studying The Relationship Between Organizational Culture (Queen's Model) And Feasibility of Establishment of A Knowledge Management System In Iranian Gas Transmission Company; J. Occupational Organizational Consulting. 13(12):101-121.

[42] Kreiner, K. (2002). Tacit Knowledge Management: The Role of Artifacts. J. Know. Manage., 6(2): 112-23.

[43] Kreitner R, Kinicki, A. (2004). Organizational Behavior. NY (Arizona State University). Mc Graw Hill. 6th Ed

[44] Kripanont, N. (2007). Examining a Technology Acceptance Model of Internet Usage by Academic within Thai Buseness Schools. Victoria University Melbourne, Australia. Unpublished Dissertation.

[45] Kuncoro, Mudrajad (2003). Metode Riset untuk Bisnis dan Ekonomi. Jakarta : Erlangga

[46] Lawler, E.E., III. \& Hall, D.T. (1970). Relationship of Job Characteristics To Job Involvement, Satisfaction And Intrinsic Motivation. Journal of Applied Psychology. 54, 305-312.

[47]Lee, K., \& Allen, N. J. (2002). Organizational Citizenship Behavior and Workplace Deviance: The
Role of Affect and Cognitions. Journal of Applied Psychology, 87(1), 131-142.

[48]Leistner, F. (2010). Mastering Organizational Knowledge Flow: How To Make Knowledge Work. John Wiley \& Sons, Inc., Hoboken, New Jersey

[49] Leonard, D. (1998). Wellsprings of knowledge: Building and sustaining the sources of innovation. Boston: Harvard Business School Press.

[50]Lilleoere, A., \& Hansen, E. (2011). Knowledge-sharing enablers and barriers in pharmaceutical research and development. Journal of Knowledge Management,

[51]Lin, Hsiu-Fen, \& Lee, Gwo-Guang (2004). Perceptions of Senior Managers Toward Knowledge-Sharing Behavior. ProQuest Research Library pg. 108

[52]Lin, C.P. (2007). To Share Or Not To Share: Modeling Knowledge Sharing Using Exchange Ideology as A Moderator. Personnel Review, Vol. 36 No. 3, pp. 457 75.

[53] Magnus, J. M., \& DeChurch, L. (2005). Information Sharing and Team Performance. A Meta-Analysis. Journal of Applied Psychology, 94, pp. 535-546.

[54] Maharani, V., Troena, E.A., \& Noermijati (2013). Organizational Citizenship Behavior Role in Mediating the Effect of Transformational Leadership, Job Satisfaction on Employee Performance: Studies in PT Bank Syariah Mandiri Malang East Java. International Journal of Business and Management; Vol. 8, No. 17; ISSN 1833-3850 E-ISSN 1833-8119.

[55] Muthusamy, S.K., White, M.A., \& Carr, A. (2007). An Empirical Examination of The Role Of Social Exchanges In Alliance Performance. Journal of Managerial Issues, Vol. 19, pp. 53-76.

[56] O'Donohue, W., Sheehan, C., Hecker, R. and Holland, P. (2007). The Psychological Contract Of Knowledge Workers. Journal of Knowledge Management, Vol. 11 No. 2, pp. 73-82.

[57] Organ., D. W. (1988). Organizational Citizenship Behavior: The Good Soldier Syndrome. Lexington, MA: Lexington.

[58] Pulakos, E.D., Dorsey, D.W., \& Borman, W.C. (2003). Hiring For Knowledge-Based Competition. Managing Knowledge for Sustained Competitive Advantage Designing Strategies for Effective Human Resource Management. John Wiley \& Sons, Inc.

[59] Ramasamy, M., \& Thamaraiselvan, N. (2011). Knowledge Sharing and Organizational Citizenship Behavior. Knowledge and Process Management Volume 18 Number 4 pp 278-284 (2011) Published online in Wiley Online Library (wileyonlinelibrary.com) DOI: 10.1002/kpm.385.

[60] Robbins, S.P., \& Judge, T.A. (2013). Organizational behavior. Pearson Education, Inc., publishing as Prentice Hall.

[61]Rohman,M.Z., Solimun, Soehono, L.A. (2013). Identifikasi variabel moderasi pada pemodelan struktural dengan pendekatan interaksi Indikator tunggal Jurusan Matematika, F.MIPA, Universitas Brawijaya

[62] Ryu, S., Ho, S.H. \& Han, I. (2003). Knowledge Sharing Behavior Of Physicians In Hospitals. Expert Systems with Applications, Vol. 25 No. 1, pp. 113-22.

[63] Sani, A. (2013). Role of Procedural Justice, Organizational Commitment and Job Satisfaction on job Performance: The Mediating Effects of Organizational 


\section{International Journal of Science and Research (IJSR) \\ ISSN (Online): 2319-7064}

Index Copernicus Value (2013): 6.14 | Impact Factor (2014): 5.611

Citizenship Behavior. International Journal of Business and Management; Vol. 8, No. 15; ISSN 1833-3850 EISSN 1833-8119.

[64] Schappe, S. (1998). The Influence of Job Satisfaction, Organizational Commitment And Fairness Perceptions On Organizational Citizenship Behavior. Journal of Psychology, 132(3), 227-290 (1998).

[65] Schein, E.H. (1993). Organizational Culture and Leadership. San Francisco, CA: Jossey Bass.

[66] Schermerhorn, J.R. Jr and Bond, M.H. (1997). CrossCultural Leadership Dynamics In Collectivism And High Power Distance Settings. Leadership \& Organization Development Journal, Vol. 18 No. 4, pp. 187-93.

[67] Seba, I., Rowley, J., \& Lambert, S. (2012). Factors Affecting Attitudes And Intentions Towards Knowledge Sharing in Dubai Police Force. International Journal of Information Management, 11-20.

[68] Sekaran, Uma. (1992). Research Methods for Business: A Skill Building Approach, John Wiley, New York

[69] Shahhosseini, S., \& Nadi, M.A. (2015). Analyzing the Relationship of Organizational Trust and Organizational Culture with Knowledge Sharing Behavior in Teachers of Second Intermediate Period. Academic Journal. Vol. 10(6), pp. 722-727, 23 March, 2015 DOI: 10.5897/ERR2015.2125. Article Number: 125FC7B51405. ISSN 1990-3839

[70] Somech, Anit, \& Drach-Zahavy, Anat. (2004). Exploring Organizational Citizenship Behaviour From an Organizational Perpective: The Relationship Between Organizational Learning and Organizational Citizenship Behavior. Journal of Occupational and Organizational Psychology; 77, ProQuest pg. 281

[71] Spender, J.C. (1996). Making Knowledge The Basic Of Dynamic Theory of The Firm. Strategic Management Journal, Vol. 17. John Wiley \& Sons.

[72] Susanti, R., \& Wimbarti, S. (2012). Pengaruh Organizational Citizenship Behavior (OCB) dan Persepsi Atas Dukungan Organisasi terhadap Knowledge Sharing dan Jenis Kelamin sebagai Moderator pada Karyawan PT. Telekomunikasi Indonesia Tbk, Kandatel Yogyakarta. Jurnal Psikologi, Volume 8 Nomor 1, Juni 2012

[73] Szulanski, G. (2003). Sticky Knowledge. Barriers to Knowing in the Firm. Sage Publication.

[74] Teh, P.L. \& Sun, H. (2012). Knowledge Sharing, Job Attitudes and Organisational Citizenship Behaviour. Industrial Management \& Data Systems, Vol. 112 No. 1, pp. 64-82

[75] Teh, P.L., \& Yong, C.C. (2011). Knowledge Sharing In IS Personnel: Organizational Behavior 'S Perspective. Journal of Computer Information Systems.

[76] Tohidinia, Z., \& Mosakhani, M. (2010). Knowledge Sharing Behavior and Its Predictors. Industrial Management \& Data Systems, Vol. 110 No. 4, pp. 61131.

[77] Widarjono, A., 2010. Analisis Statistika Multivariat Terapan. UPP STIM YKPN.

[78]Zhang, P., \& Ng, F.F. (2012). Attitude Toward Knowledge Sharing In Construction Teams. Industrial Management \& Data Systems, Vol. 112 No. 9, 2012 pp. 1326-1347. Emerald Group Publishing Limited 02635577. DOI 10.1108/02635571211278956.
[79]Zboralski, K. (2009). Antecedents of Knowledge Sharing In Communities of Practice. Journal of Knowledge Management, Vol. 13 No. 3, pp. 90-101. 